\title{
Alteration of the immune response of the common marine mussel Mytilus edulis resulting from exposure to cadmium
}

\author{
Jackie A. Coles, Sophia R. Farley, Richard K. Pipe* \\ Natural Environment Research Council, Plymouth Marine Laboratory, Citadel Hill, Plymouth PL1 2PB, United Kingdom
}

\begin{abstract}
The common marine mussel Mytilus edulis was used in laboratory-controlled experiments to investigate the effects of exposure to cadmium on immune capability. Haemolymph was extracted from mussels exposed for $7 \mathrm{~d}$ to 40 and $400 \mu \mathrm{g} \mathrm{l^{-1 }}$ of cadmium, and assays were carried out to investigate the potential for immune response. The assays included total and differential haemocyte counts, the release of intracellular and extracellular reactive oxygen metabolites, phagocytosis, release of degradative enzymes and uptake of neutral red. Cadmium at $400 \mathrm{Mg} \mathrm{l}^{-1}$ resulted in significantly enhanced numbers of circulating haemocytes and increased uptake of neutral red. No alteration was demonstrated in proportions of circulating haemocyte types, phagocytosis or production of reactive oxygen metabolites. The release of degradative enzymes during phagocytosis was found to be significantly suppressed at the $40 \mathrm{\mu g} \mathrm{l}^{-1}$ cadmium concentration. Assays to determine the immune function may provide a sensitive measure of the health status of an individual or population under pollutant stress. However the variability in effects produced in different aspects of immune function emphasises the need for a multi-assay approach to monitoring pollution. The observed effects on immunocompetence, at environmentally realistic levels of contaminant, support the view that a relationship exists between pollution and immunomodulation in aquatic organisms.
\end{abstract}

KEY WORDS: Mussel $\cdot$ Immunocompetence $\cdot$ Haemolymph $\cdot$ Cadmium

\section{INTRODUCTION}

In recent years a great deal of effort has been directed towards elucidating the possible correlation between environmental pollutants and stress-related disease conditions in animals (Sindermann 1993). Bivalve molluscs, including the marine mussel Mytilus edulis, have been postulated as ideal indicator organisms for assessing levels of environmental pollution, as they are ubiquitous, sedentary filter-feeders inhabiting coastal and estuarine areas. They filter large volumes of seawater and may therefore concentrate contaminants, up to a factor of $10^{5}$, within their tissues (Widdows \& Donkin 1992). Metals usually occur in a highly soluble form in seawater, and therefore, their uptake and accumulation in filter-feeding bivalves are usually proportional to the concentration in the environment (Livingstone \& Pipe 1992).

\footnotetext{
- Addressee for correspondence
}

Cadmium is used principally in the production of stabilisers and pigments in plastic and in the electroplating industry and is also released as a by-product from other anthropogenic activities including mining, metal industries and agriculture. The total input of cadmium to the world oceans is estimated to be approximately $8000 \mathrm{t} \mathrm{yr}^{-1}$, about half of which results from human activity. There is evidence that cadmium levels in the sea and particularly in estuarine sediments may be increasing (Clark 1989).

Contaminants may exert toxic effects on an organism either by direct action on specific body tissues or more generally, by influencing homeostatic mechanisms, such as the immune system. Direct toxic effects resulting in pathological alteration of tissues have been observed in marine species, associated with exposure to cadmium at concentrations as low as $0.001 \mathrm{ppm}$. The pathological changes recorded have been reviewed by Gardner (1993) and include malformation of the gemmosclere, melanisation particularly 
of gill tissue and cuticle and necrosis of kidney, digestive diverticula and reproductive tissue. The occurrence of neoplastic lesions has also been observed (Gardner 1993).

Mussels have an open circulatory system which is continually exposed to fluctuating environmental factors including contaminants. Investigation of sublethal, toxic effects of contaminants on the immune system may therefore represent a sensitive and comprehensive measure of general health status, reflecting the degree of pollutant stress. Immune defence in mussels is comprised of cell-mediated and humoral mechanisms, in which the haemocytes play a key role (Cheng 1981). Antigenic challenge stimulates migration of haemocytes, followed by phagocytosis and intracellular degradation of the pathogen by means of lytic enzymes (Fipe 1990a) or the production of highly reactive oxygen metabolites (Pipe 1992). Degradation may also occur extracellularly following degranulation of the haemocytes.

Immunomodulation resulting from cadmium exposure has been demonstrated previously in laboratorycontrolled experiments using the bivalve Crassostrea virginica (Cheng 1988a, b, Larson et al. 1989, Anderson et al. 1992a). The aim of the present study was to investigate the effects of exposure to cadmium on a range of aspects of the immune function of Mytilus edulis. Parameters measured concentrated on mechanisms employed by the mussel for destruction of invading pathogens and included changes in the number and character of circulating haemocytes, intracellular and extracellular superoxide radical production, release of lysosomal enzymes, uptake of neutral red and phagocytic activity.

\section{MATERIALS AND METHODS}

Experimental mussels. Mytilus edulis (60 to $75 \mathrm{~mm}$ shell length) were collected at low tide from Exmouth Estuary, Devon, UK. The estuary is in an area with minimal industrial input and therefore is relatively clean. Fifty mussels were allocated to each of 3 polypropylene tanks $(26 \times 12 \times 18 \mathrm{~cm})$ containing $1 \mathrm{l}$ of aerated, filtered seawater at $15^{\circ} \mathrm{C}$ and were left overnight to acclimatize.

Cadmium exposure. The seawater was changed each day for $7 \mathrm{~d}$, after which the tanks were dosed from a stock solution of cadmium chloride dissolved in seawater, giving final cadmium concentrations of 0,40 and $400 \mu \mathrm{g} \mathrm{I}^{-1}$ The mussels were fed $300 \mathrm{ml}$ of mixed algal solution per tank twice weekly, $1 \mathrm{~h}$ prior to changing the water

Protein quantification. In most microplate assays carried out, each haemolymph sample was pipetted into a duplicate microplate and analysed for protein content using a bicinchoninic acid protein assay (Pierce Chem. Co.). The protein was solubilised using $1 \%$ CHAPS at $37^{\circ} \mathrm{C}$ for 30 min (Pierce Chem. Co.), bovine serum albumen was used as a standard and readings were obtained on the microplate reader at $550 \mathrm{~nm}$. All results were then expressed relative to haemocyte protein content.

Assays. Assays were carried out after $7 \mathrm{~d}$ of exposure. Haemolymph was extracted from the posterior adductor muscle (from 6 to 8 mussels per treatment) immediately before each assay, using a $2 \mathrm{ml}$ syringe fitted with a 21 gauge needle.

Total and differential counts: Haemolymph samples were withdrawn into an equal volume of Baker's formol calcium, containing $2 \%$ sodium chloride. The samples were mixed and allowed to tix. lotal cell counts were performed using a haemocytometer (improved Neubauer). Blood cells were prepared for differential counts using a cytocentrifuge (Shandon); $250 \mu \mathrm{l}$ of haemolymph was spun at $170 \times g$ onto glass microscope slides. Cells were then post-fixed in methanol for 10 min, stained with Wright's stain (Gurr, BDH) for 2 min, rinsed in water, air dried and mounted in Canada balsam. Relative numbers of eosinophils and basophils were calculated by counting 300 blood cells from each mussel.

Superoxide generation: Haemolymph was extracted into an equal volume of $0.05 \mathrm{M}$ Tris- $\mathrm{HCl}$ buffer, $\mathrm{pH} 8.2$, containing $2 \% \mathrm{NaCl}$. Aliquots of $100 \mu \mathrm{l}$ of each were pipetted into microplate wells in replicates of 8 .

Cytochrome-C reduction: Cytochrome-C solution (100 $\mu \mathrm{l}$ aliquots of $80 \mu \mathrm{M}$ cyt-C in Tris- $\mathrm{HCl}$ buffer) was added to 4 wells for each of 6 samples and cytochromeC solution containing 300 units ml $^{-1}$ of superoxide dismutase (SOD) (Sigma Chem. Co.) added to the remaining 4 wells. A stimulant (such as phorbol myristate acetate) was not found to be necessary as previous studies have determined that experimental manipulation is sufficient to activate the cells and elicit superoxide generation (Pipe 1992, Coles et al. 1994). Wells containing cells in buffer only and cytochrome-C solution without cells were prepared as negative controls. The optical density (OD) was read immediately at $20^{\circ} \mathrm{C}$ on an Anthos HTII microplate reader, using a narrow band-width, $550 \mathrm{~nm}$ filter and a kinetics programme, taking readings every $30 \mathrm{~s}$ over a $20 \mathrm{~min}$ period. The results were expressed as unit changes in OD over $20 \mathrm{~min} \mathrm{mg}^{-1}$ protein.

Nitroblue tetrazolium salt (NBT) reduction: NBT solution $\left(2 \mathrm{mg} \mathrm{ml}^{-1}\right)$ dissolved in Tris- $\mathrm{HCl}$ buffer $(100 \mu \mathrm{l}$ aliquots) was added to 4 replicate microplate wells of each of 6 haemolymph samples. NBT solution containing 300 units $\mathrm{ml}^{-1}$ of SOD was added to the remaining 4 wells. Blood cells in buffer only and NBT solution without cells were used as blank control samples. The 
plates, wrapped in foil, were incubated for 20 min at $10^{\circ} \mathrm{C}$, after which the cells were centrifuged at $120 \times \mathrm{g}$ for $10 \mathrm{~min}$, washed twice in buffer and fixed for $10 \mathrm{~min}$ in methanol. The plates were then centrifuged at $300 \times$ $g$ for a further $10 \mathrm{~min}$ and the cells allowed to air dry. After 5 further washes in $50 \%$ methanol, the cells were solubilised in $140 \mu$ of dimethyl sulfoxide (DMSO) (Sigma Chem. Co.), followed by $120 \mu$ of $2 \mathrm{M} \mathrm{KOH.}$ The plates were read using a $620 \mathrm{~nm}$ filter and the results expressed as OD $\mathrm{mg}^{-1}$ protein.

Phagocytosis: A method was developed to assess the total phagocytic uptake capability of the blood cells using a microplate reader. Haemolymph was withdrawn into an equal volume of anticoagulant buffer (0.05 M Tris- $\mathrm{HCl}, \mathrm{pH} 7.6$, containing $2 \%$ glucose, $2 \%$ $\mathrm{NaCl}$ and $0.5 \%$ EDTA). Aliquots of $50 \mu \mathrm{l}$ of each sample were pipetted into 12 replicate microplate wells. An equal volume of neutral-red-stained, heat-stabilised, zymosan suspension (Sigma Chem. Co.), containing $1 \times 10^{8}$ particles $\mathrm{ml}^{-1}$ in anticoagulant buffer, was added to each well. Aliquots of zymosan suspension in anticoagulant buffer alone were used as controls and aliquots of heat-killed cells in zymosan suspension were used as blanks. The microplates were incubated for $25 \mathrm{~min}$ at $10^{\circ} \mathrm{C}$, and the process was stopped by adding $100 \mu \mathrm{l}$ aliquots of Baker's formol calcium, con-

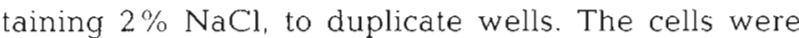
allowed to fix for $10 \mathrm{~min}$, after which they were centrifuged at $70 \times g$ for 5 min and washed several times in buffer. Suspensions of known zymosan concentrations were aliquoted $(50 \mu \mathrm{l})$ to duplicate wells just prior to the last centrifugation to provide a standard curve. Acetic acid (1\%) in 50\% ethanol $(100 \mu l)$ was added to each well to solubilise the neutral red and the plate allowed to stand for $5 \mathrm{~min}$. The OD was then read at $550 \mathrm{~nm}$ and the results expressed as zymosan concentration phagocytosed $\mathrm{mg}^{-1}$ of haemocyte protein.

Release of degradative enzymes: The release of $\mathrm{N}$ acetyl- $\beta$-D-glucosaminidase (NAG) was measured. Haemolymph was withdrawn into anticoagulant buffer and $50 \mu \mathrm{l}$ aliquots were pipetted into 8 replicate microplate wells. Zymosan suspensions $(50 \mu l)$ of $0.0125,0.025$ and $0.05 \%$ in anticoagulant buffer were added to the wells in duplicate and buffer alone added to the remaining 2 wells. The plates were left to incubate for $1 \mathrm{~h}$ at $10^{\circ} \mathrm{C}$, after which they were centrifuged at $300 \times g$ for $10 \mathrm{~min}$. Supernatant $(50 \mu \mathrm{l})$ was then removed and placed into corresponding wells of a clean plate. To each was added $50 \mu$ of the substrate, P-nitrophenyl-N-acetyl- $\beta$-D-glucosaminide (dissolved in $2.5 \mathrm{ml}$ of dimethyl sulfoxide and diluted to $15 \mathrm{mM}$ in anticoagulant buffer) and $50 \mu \mathrm{l}$ of anticoagulant buffer. The plates were incubated for a further $20 \mathrm{~min}$ at $20^{\circ} \mathrm{C}$, after which $100 \mu \mathrm{l}$ of stopping buffer $(0.4 \mathrm{M}$ glycine buffer, pH 10.4) was added. A standard curve was pre- pared using P-nitrophenol and wells containing all solutions but without blood cells were used as blanks The OD was read at $340 \mathrm{~nm}$. Enzyme release was found to be optimal upon stimulation with $0.05 \%$ zymosan and therefore the results were expressed as $\mu \mathrm{M}$ of enzyme released $\mathrm{mg}^{-1}$ of haemocyte protein at this concentration of zymosan.

Uptake of neutral red: Haemolymph was withdrawn into an equal volume of anticoagulant buffer and $100 \mu \mathrm{l}$ aliquots of each sample pipetted into 3 replicate microplate wells. Aliquots $(10 \mu l)$ of $0.33 \%$ neutral red (Sigma Chem. Co.) solution in phosphate buffered saline (PBS) containing $2 \% \mathrm{NaCl}$ were added to each well and the plate incubated for $1 \mathrm{~h}$ at $10^{\circ} \mathrm{C}$. The cells were then centrifuged at $200 \times g$ for $5 \mathrm{~min}$ and washed twice in buffer. Aliquots (100 $\mu$ l) of $1 \%$ acetic acid in $50 \%$ ethanol were added to all wells. The plates were incubated, covered with foil, for $15 \mathrm{~min}$ at $20^{\circ} \mathrm{C}$ and then read at $550 \mathrm{~nm}$. Protein analysis was carried out on duplicate wells and the results expressed as OD $\mathrm{mg}^{-1}$ protein.

Cadmium analysis. Lysosomal compartments, particularly those in the digestive gland, represent the major site of metal accumulation in bivalve molluscs (Livingstone \& Pipe 1992). The digestive gland was removed from 6 mussels from each treatment and placed into PBS containing $2 \% \mathrm{NaCl}$. The tissues were then digested in concentrated nitric acid at $20 \mathrm{ml} \mathrm{g}^{-1}$ dry wt, heat-evaporated and made up in $10 \%$ hydrochloric acid. Analysis for cadmium content was then carried out by flame atomic absorption spectrophotometry, using deuterium arc background correction for $\mathrm{NaCl}$ (Bryan et al. 1985)

Statistical analysis. Results of all assays were analysed statistically using 1- or 2-way analysis of variance (Systat), Mean values are expressed $\pm 1 \mathrm{SE}$.

\section{RESULTS}

\section{Cadmium analysis}

Analysis of the cadmium content of the digestive gland tissue of mussels demonstrated increasing tissue levels with increasing cadmium administered (Table 1).

Table 1. Mytilus edulis. Levels of cadmium found in the digestive gland tissue of mussels exposed to cadmium for $7 \mathrm{~d}$

\begin{tabular}{|cc|}
\hline Exposure level $\left(\mu \mathrm{g} \mathrm{I}^{-1}\right)$ & Level in tissue $\left(\mu \mathrm{g} \mathrm{g}^{-1} \mathrm{dry} w \mathrm{t}\right)$ \\
\hline 0 & 2.87 \\
40 & 7.37 \\
400 & 99.81
\end{tabular}




\section{Assays}

No mortalities were produced in either control or cadmium exposed mussels.

\section{Total and differential cell counts}

The effect of cadmium on the total number of circulating haemocytes in Mytilus edulis is shown in Fig. 1. Exposure to $400 \mu \mathrm{g} \mathrm{l}^{-1}$ of cadmium resulted in a significant increase in haemocyte number to $13 \times 10^{6}$ cells $\mathrm{ml}^{-1}$, as compared to $8 \times 10^{6}$ cells $\mathrm{ml}^{-1}$ in the control mussels ( $p=0.021$ ) and $5.7 \times 10^{6}$ cells $\mathrm{ml}^{-1}$ in the mussels exposed to $40 \mathrm{\mu g} \mathrm{l}^{-1}$ of cadmium ( $\mathrm{p}=0.001$ ).

lhe difterentiai counts identified basophilic and eosinophilic cells. The basophilic haemocytes ranged from small hyalinocytes to cells containing numerous small granules, the eosinophilic haemocytes contained large granules (Pipe 1990b). The effect of cadmium exposure on the percentage of circulating eosinophilic to basophilic cells is shown in Table 2. Exposure did not result in any significant fluctuations in proportion of blood cell types.

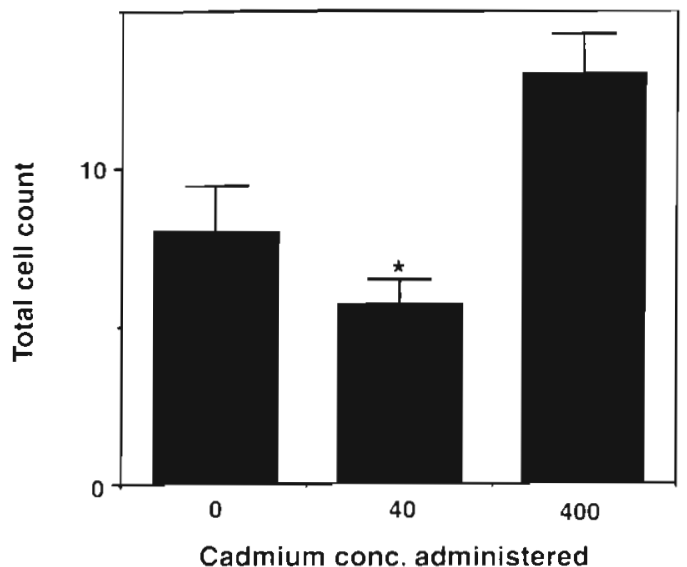

Fig. 1. Mytilus edulis. Total number of circulating haemocytes $\left(\times 10^{6}\right.$ cells $\mathrm{ml}^{-1}$ ) in the haemolymph of mussels exposed to different concentrations of cadmum ( $\left.\mu \mathrm{g} \mathrm{l}^{-1}\right)$ for $7 \mathrm{~d}$. *Significant $(p<0.05)$

\section{Superoxide generation}

The results of cadmium exposure on generation of superoxide radicals by Mytilus edulis haemocytes are shown in Table 2 . Both cytochrome-C reduction, measuring extracellular superoxide release, and NBT reduction, measuring intracellular superoxide release, showed no significant variation between mussels from control or exposed tanks.
Table 2. Mytilus edulis. Effects of $7 \mathrm{~d}$ cadmium exposure on proportions of circulating cell types, extracellular and intracellular superoxide production and phagocytic activity by haemocytes. Extracelluidr superoxide is measured by the reduction of cytochrome-C (change in OD over $20 \mathrm{~min} \mathrm{mg}^{-}$ haemocyte protein), intracellular superoxide by reduction of nitroblue terazolium salt (OD $\mathrm{mg}^{-1}$ haemocyte protein) and phagocytosis by uptake of neutral-red stained zymosan (no. of zymosan particles $\times 10^{10} \mathrm{mg}^{-1}$ haemocyte protein)

\begin{tabular}{|lccc|}
\hline & \multicolumn{3}{c}{ Exposure level $\left(\mathrm{kg} \mathrm{l}^{-1}\right)$} \\
& $0 \mu \mathrm{gl}^{-1}$ & $40 \mu \mathrm{I} \mathrm{I}^{-1}$ & $400 \mu \mathrm{gl}^{-1}$ \\
\hline $\begin{array}{l}\text { Eosinophils: } \\
\text { basophils (\%) }\end{array}$ & $49.51 \pm 1.9$ & $43.57 \pm 3.1$ & $52: 48 \pm 3.0$ \\
$\begin{array}{l}\text { Extracellular } \\
\text { superoxide }\end{array}$ & $0.094 \pm 0.009$ & $0.075 \pm 0.008$ & $0.079 \pm 0.01$ \\
$\begin{array}{l}\text { Intracellular } \\
\text { superoxide } \\
\text { Phagocytosis }\end{array}$ & $0.138 \pm 0.048$ & $0.095 \pm 0.029$ & $0.167 \pm 0.045$ \\
\hline
\end{tabular}

\section{Phagocytosis}

Table 2 shows the effect of cadmium exposure on the phagocytic activity of mussel haemocytes following $25 \mathrm{~min}$ incubation. Cadmium at $400 \mu \mathrm{g} \mathrm{l}^{-1}$ resulted in a significant $(p=0.016)$ decrease in phagocytosis of zymosan as compared to mussels exposed to $40 \mu \mathrm{g} 1^{-1}$ cadmium but this decrease in phagocytosis was not statistically significant when compared with control mussels.

\section{Release of degradative enzymes}

Fig. 2 shows the effect of cadmium exposure on zymosan-stimulated release of $N$-acetyl- $\beta$-D-glucosaminidase by mussel haemocytes. Cadmium at $40 \mu \mathrm{g}$ $1^{-1}$ produced a significant $(p=0.01)$ suppression in the release of NAG as compared to both the control mussels and those exposed to $400 \mathrm{\mu g} \mathrm{l}^{-1}$ cadmium. The higher cadmium level appeared to stimulate NAG release but this was not significantly different from the control value.

\section{Uptake of neutral red}

Fig. 3 shows the effect of cadmium exposure on the uptake of neutral red by mussel blood cells. Cadmium

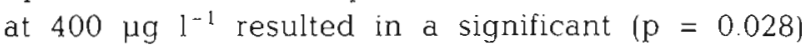
increase in uptake of the dye by the haemocytes as compared to control mussels. Cadmium at $40 \mu \mathrm{g} \mathrm{I}^{-1}$ resulted in a slight but non-significant ( $p=0.430)$ increase in uptake by the haemocytes. 


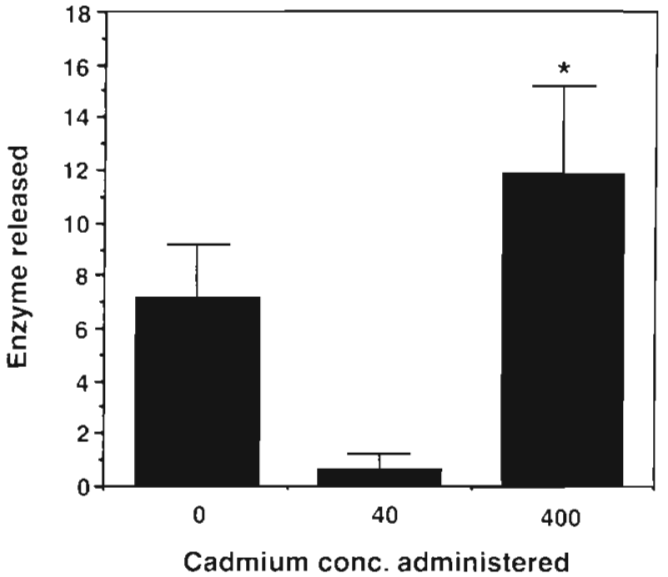

Fig. 2. Mytilus edulis. Zymosan-stimulated release of $\mathrm{N}$ acetyl- $\beta$-D-glucosaminidase $\left(\mu \mathrm{M}\right.$ of enzyme $\mathrm{mg}^{-1}$ of haemocyte protein) from haemocytes of mussels exposed to different concentrations of cadmium $\left(\mu \mathrm{g}^{-1}\right)$ for $7 \mathrm{~d}$. *Significant $(\mathrm{p}<0.05)$

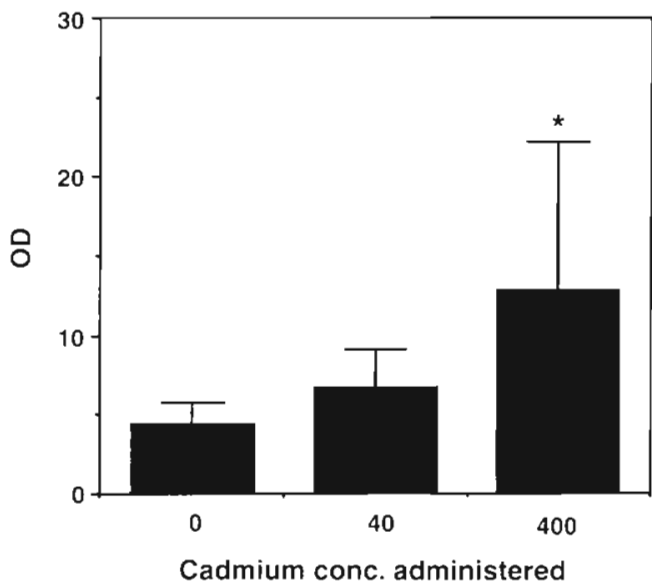

Fig. 3. Mytilus edulis. Uptake of neutral red $\left(\mathrm{OD} \mathrm{mg}^{-1}\right.$ of haemocyte protein) by haemocytes of mussels exposed to different concentrations of cadmium $\left(\mu \mathrm{g}^{-1}\right)$ for $7 \mathrm{~d}$. *Significant $(p<0.05)$

\section{DISCUSSION}

Immunomodulation associated with exposure to cadmium has been observed previously in a range of species. Altered haematological parameters and effects on immune function have been found in both fish (Zelikoff 1993) and bivalves (Anderson 1993).

In the present study, exposure to cadmium over a $7 \mathrm{~d}$ period was carried out at environmentally realistic levels of 40 and $400 \mu \mathrm{g} \mathrm{ml}^{-1}$. Cadmium levels of more than $50 \mathrm{\mu g} \mathrm{l}^{-1}$ (Bryan \& Langston 1992) and $210 \mu \mathrm{g} \mathrm{l}^{-1}$ (W. J. Langston pers. comm.) have been recorded at Restronguet Creek, Cornwall, UK. These experimental levels have been shown to produce elevated levels of cadmium in the digestive gland tissue of the mussel and to affect significantly several aspects of immune function. Exposure to cadmium at $400 \mu \mathrm{g} \mathrm{l}^{-1}$ resulted in a significant increase in the total number of circulating haemocytes whilst not affecting the relative proportions of eosinophilic to basophilic cell types. Elevation in total blood cell numbers seems to be a common response to environmental stressors. Exposure of Mytilus edulis to fluoranthene (Coles et al. 1994) or exposure to phenol or stress by temperature manipulation (Renwrantz 1990) resulted in increased total blood cell counts, of which the last was found to be reversible on withdrawal of the stressor. Exposure of Crassostrea virginica to cadmium (Cheng 1988a) or to a protozoan parasite (Anderson et al. 1992b) also stimulated circulating blood cell numbers and a reversible increase in cells was found to occur $72 \mathrm{~h}$ after exposure of 2 clam species, Ruditapes philippinarum and $R$. decussatus, to pathogenic bacteria (Oubella et al. 1993). These relatively rapid, reversible responses suggest that increased total numbers of circulating haemocytes occurs by stimulation of migration of the cells from tissues, rather than by blood cell proliferation. This may or may not result in altered relative proportions of haemocyte types depending on the distribution within the tissues of blood cell types in a particular individual or species. The diverse nature of the stimulants suggests that this is a general response to an environmental stressor rather than a reaction to a specific challenge.

The present results show that cadmium exposure also significantly affected some aspects of haemocyte function. The production of superoxide radicals by the haemocytes is postulated to play an important role in intra-and extracellular killing of invasive pathogens in invertebrates (Adema et al. 1991) as well as vertebrates. Alteration of the chemiluminescent response, measuring the production of reactive oxygen metabolites by haemocytes, has been found in association with high levels of polynuclear aromatic hydrocarbons (PAHs) in several fish species (Weeks et al. 1990a, b) and in association with cadmium exposure in the carp (Elasser et al. 1986). Exposure to cadmium in vitro has been found to affect haemocyte chemiluminescent activity in the oyster, Crassostrea virginica (Larson et al. 1989, Anderson et al. 1992a). However, this occurred at relatively high environmental levels of dissolved cadmium (10 to $320 \mathrm{ppm}$ ); in vivo exposure, up to $0.25 \mathrm{ppm}$, did not result in significant alterations in chemiluminescence (Anderson et al, 1992a). The production of superoxide radicals by immune cells was not found to be significantly altered by exposure to the environmentally realistic levels of cadmium used in this study. 
Phagocytosis prior to intracellular degradation of invasive antigens comprises an integral part of cellular defence in organisms. Environmental stressors are postulated to be capable of reducing immunocompetence by altering the phagocytic activity of haemocytes. Depressed phagocytic activity by haemocytes of various species of fish have been found associated with high levels of PAHs (Weeks et al. 1989, Weeks et al. 1990a, b, Seeley \& Weeks-Perkins 1991). In molluscs phenol exposure was found to depress phagocytosis by haemocytes of Merceneria merceneria (Fries \& Tripp 1980) whereas long-term, in vitro exposure to benzo(a)pyrene, pentachlorophenol and hexachlorobenzene produced a slight increase in phagocytic activity in this clam (Anderson 1981). Heavy metals have also been found to alter phagocytic activity. Exposure in vivo to 1 ppm cobalt, 5 ppm chromium, 5 ppm copper, 1 and 5 ppm iron, 0.1 ppm mercury and 5 ppm selenium resulted in increased phagocytosis by the haemocytes of Crassostrea virginica and 0.5 to 5 ppm mercury significantly decreased phagocytosis, whereas 1 and 5 ppm cadmium produced no effect (Cheng \& Sullivan 1984). Exposure of $C$. virginica, for 1 to $2 \mathrm{wk}$ in vivo, to 1 ppm copper and 1 ppm cadmium resulted in an inhibitory effect by the former and stimulation of phagocytosis by the latter (Cheng 1988b). In the present study, $7 \mathrm{~d}$ exposure of Mytilus edulis to $40 \mu \mathrm{g} \mathrm{l^{-1 }}$ cadmium produced a stimulation of phagocytosis by the haemocytes, whereas $400 \mu \mathrm{gl}^{-1}$ resulted in a slight inhibition. However, although significantly different to each other, these alterations are not significantly different to the control values when comparing 6 mussels Further experiments using more mussels would possibly demonstrate alteration in phagocytic activity due to cadmium exposure by reducing the effects of the variability observed between individuals

The uptake of neutral red by mussel haemocytes may occur by pinocytosis or passive diffusion across the cell membrane. Neutral red is a cationic dye which accumulates in the lysosomal compartment of cells. Alteration in its uptake may reflect damage to the plasma membrane of the blood cells or alternatively, may represent changes in the volume of the lysosomal compartment. In the present study, uptake of neutral red was significantly increased on exposure to $400 \mu \mathrm{g}$ $1^{-1}$ cadmium. Depressed phagocytosis together with increased neutral red uptake by macrophages was also demonstrated in studies on several fish species captured from highly polluted areas (Weeks et al. 1989). This effect may demonstrate the ability of certain contaminants, including cadmium, to alter the permeability of blood cell membranes as postulated by Pickwell \& Steinert (1984)

The potential for microbicidal activity by release of degradative enzymes during phagocytosis is another important method of cellular, immune defence in invertebrates. The presence of a range of lysosomal enzymes has been demonstrated previously in the granules of Mytilus edulis haemocytes (Pipe 1990a). Pickwell \& Steinert (1984), working on $M$. edulis, found an increase in release of degradative enzymes into haemolymph under cupric ion stress and postulated that this resulted from disruption of lysosomal membranes. Cheng (1989), however, found stimulation of $\beta$-glucuronidase activity by copper exposure in Crassostrea virginica but inhibition, by both copper and cadmium, of the release of this enzyme and acid phosphatase into the haemolymph. More recently, Coles et al. (1994) demonstrated inhibition by fluoranthene of the release of chymotrypsin-like enzyme by blood cells of $M$. edulis. This study demonstrates that exposure of mussels to cadmium at $40 \mu \mathrm{g} \mathrm{I}^{-1}$ may result in a significant inhibition of the release of the glycolytic enzyme NAG into the haemolymph. Cadmium at $400 \mu \mathrm{g} \mathrm{l}^{-1}$ resulted in an increase in enzyme release although not to a significant degree. Contrasting effects produced by lower and higher levels of contaminant are commonly demonstrated and may signify that a threshold level of contaminant may be an important concept when assessing immunomodulation (Larson et al. 1989). The variation in effects on enzyme release by different stressors suggests that these may result from a specific interaction between the chemical and its target, rather than representing a general stress response.

Overall, this study demonstrates that short-term cadmium exposure, at environmentally realistic levels, may affect various aspects of immune function in Mytilus edulis, with the possible consequence of an impaired defence capability and increased disease susceptibility of an individual or population. Indeed, the lower concentration of $40 \mu \mathrm{g} \mathrm{l}^{-1}$ produced a more significant alteration in the release of NAG from the blood cells. The variation found in the extent and nature of the response to a contaminant and the difference in the responses observed as compared to those in different species emphasise the need for a multiassay and multi-species approach to the study of effects on immunocompetence. The assays used, when combined, may therefore represent a sensitive means of testing for environmental stressors and their possible effects on disease susceptibility in aquatic organisms. Further research is needed to test for the potentially more harmful effects on disease susceptibility of long-term exposure to contaminants.

Acknowledgements. The authors acknowledge the financial assistance provided by The Commission of the European Community Research Programme on the Fisheries Sector (FAR), Project Numbers AQ2 419 and AQ3 633, and the UK 
Dept of the Environment (PECD Ref. $7 / 7 / 386$ ). We also thank $\mathrm{Mr} \mathrm{G}$. Burt for his work on cadmium analysis and Mr M. Carr for advice on statistics.

\section{LITERATURE CITED}

Adena CM, van der Knapp WPM. Smınia T (1991) Molluscan haemocyte-mediated cytotoxicity: the role of reactive oxygen intermediates. Rev aquat Sci 4:210-223

Anderson RS (1981) Effects of carcinogenic and non-carcinogenic environmental pollutants on immunological functions in marine invertebrates. In: Dawe CJ, Harshbarger JC, Kondo S, Sagimura T, Takayama S (eds) Phylogenetic approach to cancer. Japan Scientific Society Press, Tokyo, p 319-331

Anderson RS (1993) Modulation of non-specific immunity by environmental stressors. In: Couch JA, Fournie JW (eds) Advances in fisheries science: pathobiology of marine and estuarine organisms. CRC Press, Boca Raton, p 483-510

Anderson RS, Oliver LM, Jacobs D (1992a) Immunotoxicity of cadmium for the eastern oyster (Crassostrea virginica Gmelin, 1791): effects on haemocyte chemiluminescence. J Shellfish Res 11(1):31-35

Anderson RS, Paynter KT, Burreson EM (1992b) Increased reactive oxygen intermediate production by hemocytes withdrawn from Crassostrea virginica infected with Perkinsus marinus. Biol Bull 183:476-481

Bryan GW, Langston WJ (1992) Bioavailability, accumulation and effects of heavy metals in sediments with special reference to United Kingdom estuaries: a review. Environ Poll 76:89-131

Bryan GW, Langston WJ, Hummerstone LG, Burt GR (1985) A guide to the assessment of heavy-metal contamunation in estuaries using biological indicators. Occasional publication no. 4, Marine Biological Association of the United Kingdom, Plymouth

Cheng TC (1981) Bivalves. In: Ratcliffe NA, Rowley AF (eds) Invertebrate blood cells 1 Academic Press, London, $p$ $233-300$

Cheng TC (1988a) In vivo effects of heavy metals on cellular defense mechanisms of Crassostrea virginica: total and differential haemocyte counts. J Invertebr Pathol 51: $207-214$

Cheng TC (1988b) In vivo effects of heavy metals on cellular defense mechanisms of Crassostrea virginica: phagocytic and endocytotic indices. $J$ Invertebr Pathol 51:215-220

Cheng TC (1989) Immunodeficiency diseases in marine mollusks: measurements of some variables. J Aquat Anim Health 1:209-216

Cheng TC, Sullivan JT (1984) Effects of heavy metals on phagocytosis by molluscan hemocytes. Mar environ Res $14: 305-315$

Clark RB (1989) Marine pollution. Oxford University Press, Oxford

Coles JA, Farley SR, Pipe RK (1994) The effects of fluoranthene on the immunocompetence of the common marine mussel, Mytilus edulis. J Aquat Toxicol 30:367-379

Elasser MS, Roberson BS, Hetrick FM (1986) Effects of metals on the chemiluminescent response of rainbow trout ( $\mathrm{Sal}$ mo gairdneri) phagocytes. Vet Immunol Immunopathol 12:243-250

Fries CR, Tripp MR (1980) Depression of phagocytosis in Mer- ceneria following chemical stress. Dev comp lmmunol 4 : $233-244$

Gardner GR (1993) Chemically induced histopathology in aquatic invertebrates. In: Couch JA, Fournie JW (eds) Advances in fisheries science: pathobiology of marine and estuarıne organisms. CRC Press, Boca Raton, p 359-391

Larson KG, Roberson BS, Hetrick FM (1989) Effect of environmental pollutants on the chemiluminescence of hemocytes from the American oyster Crassostrea virginica. Dis aquat Org 6:131-136

Livingstone DR, Pipe RK (1992) Mussels and environmental contaminants: molecular and cellular aspects. In: Gosling E (ed) The mussel Mytilus: ecology, physiology, genetics and culture. Elsevier, Amsterdam, p 425-464

Oubella R, Maes P, Paillard C. Auffret M (1993) Experimentally induced variation in hemocyte density for Ruditapes philippinarum and $R$. decussatus (Mollusca, Bivalvia). Dis aquat Org 15:193-197

Pickwell GV, Steinert SA (1984) Serum biochemical and cellular responses to experimental cupric ion challenge in mussels. Mar environ Res 14:245-265

Pipe RK (1990a) Hydrolytic enzymes associated with the granular haemocytes of the marine mussel, Mytilus edulis. Histochem J 22:595-603

Pipe RK (1990b) Differential binding of lectins to haemocytes of the mussel Mytilus edulis. Cell Tissue Res 261:261-268

Pipe RK (1992) Generation of reactive oxygen metabolites by the haemocytes of the mussel, Mytilus edulis. Dev comp Immunol 16:111-122

Renwrantz L (1990) Internal defence system of Mytilus edulis. In: Stefano GB (ed) Studies in neuroscience, neurobiology of Mytilus edulis. Manchester University Press, Manchester, p 256-275

Seeley KR, Weeks-Perkins BA (1991) Altered phagocytic activity of macrophages in oyster toadfish from a highly polluted subestuary. J Aquat Anim Health 3:224-227

Sindermann CJ (1993) Interactions of pollutants and disease in marine fish and shellfish. In: Couch JA, Fournie JW (eds) Advances in fisheries science: pathobiology of marine and estuarine organisms. CRC Press, Boca Raton, p 451-482

Weeks BA, Huggett RJ, Warinner JE, Mathews ES (1990b) Macrophage responses of estuarine fish as bioindicators of toxic contamination. In: McCarthy JF, Shugart LR (eds) Biomarkers of environmental contamination. Lewis Publishers, CRC Press, Boca Raton, p 193-201

Weeks BA, Warinner JE, Mathews ES, Wishkovsky A (1990a) Effects of toxicants on certain functions of the lymphoreticular system of fish. In: Perkins FO, Cheng TC (eds) Pathology in marine science. Academic Press, San Diego, p 369-374

Weeks BA, Warinner JE, Rice CD (1989) Recent advances in the assessment of environmentally-induced immunomodulation. In: Oceans ' 89 proceedings, Vol 2. Institute of Electrical and Electronics Engineers, New York, p $408-411$

Widdows J, Donkin P (1992) Mussels and environmental contaminants: bioaccumulation and physiological aspects. In: Gosling E (ed) The mussel Mytilus: ecology, physiology, genetics and culture. Elsevier, Amsterdam, p 383-424

Zelikoff JT (1993) Metal pollution-induced immunomodulation in fish. In: Annual review of fish diseases. Pergamon Press, Oxford, p 305-325

Manuscript first received: July 6, 1994

Revised version accepted: December 15, 1994
Responsible Subject Editor: D. E. Hinton, Davis, California, USA 